\title{
LARANGAN PRAKTEK MONOPOLI DAN PERSAINGAN USAHA TIDAK SEHAT DALAM INDUSTRI SEPEDA MOTOR (KAJIAN PUTUSAN MAHKAMAH AGUNG NOMOR 217 K/PDT.SUS- KPPU/2019)
}

\author{
Gilang Yudha Wirawan, Hartanto* \\ Faculty of Law, Widya Mataram University \\ hartanto.yogya@gmail.com
}

\begin{abstract}
Submitted: 2020-11-10| Reviewed:
How to cite: Gilang Yudha Wirawan, Hartanto. "Larangan Praktek Monopoli dan Persaingan Usaha Tidak Sehat dalam Industi Sepeda Motor (Kajian Putusan Mahkamah Agung Nomor 217 L/PDT.SUS-KPPU/2019)". Dialogia Iuridica: Jurnal Hukum Bisnis dan Investasi, Vol. 12, No. 2, (2021): 050068.
\end{abstract}

\section{DOI:}

https://doi.org/10.28932/di.v12i2.3121

\section{ABSTRACT}

Business competition is an economic activity that runs in line with technological and industrial advances. With the existence of business competition, the Business Competition Supervisory Commission in Indonesia was formed which aims to s upervise and protect business competition. This research will discuss the impact and legal consequences of the KPPU decision to the Supreme Court decision which still considers and uses circumstantial evidence and testimony based on hearing from other people. Based on the description above, the writer chooses the research title "Judicial Review of the Prohibition of Monopolistic Practices and Unfair Business Competition in the Motorcycle Industry (Supreme Court Decision No. 217 K / Pdt.Sus-KPPU / 2019 decision studies) with the formulation of the problem of legal impact from the Assembly's decision. The Cassation Judge is proven not to have considered and examined the objections / demands of the Cassation Appellant as well as whether the legal consequences of the decision of the Cassation Panel of Judges used indirect evidence in the form of other people's
\end{abstract}


testimony (testimonium de auditu), as the basis for the decision. Meanwhile, according to the author's hypothesis this is not quite right. So the authors want to examine the problems associated with these norms and use normative research methods, with using interviews as supporting data.

Keywords: Monopoly; Business Competition; Indirect Evidence

\section{PENDAHULUAN}

Persaingan usaha yang masif terjadi, diharapkan dapat menciptakan kekuatan pasar yang menyebar (tidak terkonsentrasi), sehingga pertumbuhan ekonomi akan semakin baik, dan tentu saja tidak dikuasai oleh golongan pengusaha atau pelaku usaha tertentu. Keadaan ini akan membuka lapangan usaha yang lebih luas bagi perusahaan lain sehingga dapat diharapkan mendorong pertumbuhan usaha-usaha wiraswasta. Mengupayakan adanya persaingan usaha yang sehat antar perusahaan juga merupakan proses efisiensi.

Undang-undang larangan persaingan usaha tidak sehat yang berasaskan demokrasi ekonomi, merupakan instrumen yang otomatis berperan penting seiring dengan perkembangan dunia usaha bahkan jika dikaitkan era globalisasi. Regulasi ini mengatur keseimbangan "daya tawar" antara kepentingan pelaku usaha dan kepentingan masyarakat sebagai konsumen, serta menjamin persaingan usaha yang fear antara para pelaku usaha ${ }^{1}$. Hal ini sesuai pula dengan pendapat Arliman bahwa sejatinya, keberadaan hukum diharapkan berpihak pada kepentingan masyarakat secara luas yaitu keadilan, dan kebaikan ${ }^{2}$

Praktik monopoli dan persaingan usaha tidak sehat dapat memunculkan hambatan terhadap bekerjanya mekanisme pasar secara wajar, sehingga dapat menghambat pertumbuhan ekonomi dan perdagangan suatu negara. Oleh karena itu, peraturan perundangundangan yang mengatur praktek monopoli dan persaingan usaha tidak sehat sangatlah dibutuhkan untuk memperbaiki ekonomi suatu bangsa.

Komisi Pengawas Persaingan Usaha (KPPU) memiliki sifat kewenangan independen dan bersifat quasi judicial, dimana kewenangan yang diberikan oleh Undang-Undang dapat melakukan penyelidikan, pemeriksaan dan mempunyai persidangannya sendiri, sehingga memutus suatu perkara tanpa adanya campur tangan dari instansi pemerintah. Lebih lanjut mengenai tugas pokok KPPU diatur dalam Pasal 30 ayat (1), (2), dan (3) UU No. 5 Tahun 1999 tentang Larangan Praktik Monopoli dan Persaingan Usaha Tidak Sehat

Dugaan adanya praktek monopoli dan persaingan usaha tidak sehat di industri otomotif yakni sepeda motor yang terjadi di Jakarta berdasarkan Putusan Mahkamah Agung No.217 K/Pdt.Sus-KPPU/2019 inilah salah satu dugaan yang harus dikaji lebih lanjut guna

\footnotetext{
${ }^{1}$ Supriatna, "Persekongkolan Bisnis Dalam Bentuk Perjanjian Kartel", Jurnal Hukum Positum, Vol. 1, No. 1, Desember 2016, hlm. 138

${ }^{2}$ Laurensius Arliman S, "Mewujudkan Penegakan Hukum Yang Baik Di Negara Hukum Indonesia", Dialogia Iuridica, Volume 11 Nomor 1, November 2019, hlm. 2
} 
membuktikan apakah benar dugaan terjadinya kekeliruan dalam pertimbangan putusan. Kasus ini menarik karena menimbulkan pertanyaan, apakah bisa indirect evidence (bukti tidak langsung yang tidak diperkuat dengan direct evidence atau alat bukti langsung) dan testimonium de auditu (kesaksian atau keterangan karena mendengar orang lain) menjadi barang bukti di pengadilan, dalam perkara ini indirect evidence yang memiliki peran cukup menentukan terhadap putusan perkara. Disisi lain penulis sependapat dengan Frans, bahwa ambiguitas bahasa dalam teks hukum ditengarai sebagai penyebab utama ketidakpastian hukum. Ini disebabkan ambiguitas merupakan property internal yang selalu ada dalam makna leksikal maupun gramatikal ${ }^{3}$. Komisi Pengawas Persaingan Usaha atau disingkat KPPU, yang menggunakan pro justitia dalam penyelidikannya, yang kita ketahui bahwa KPPU merupakan lembaga administratif.

Penelitian terkait KPPU cukup banyak, antara lain Analisis Putusan Nomor 09/KppuL/2009 Dan Putusan Mahkamah Agung Nomor 502 K/Pdt.Sus/2010 Tentang dugaan Kasus monopoli dan Persaingan Usaha Tidak Sehat Yang Dilakukan Oleh PT Carrefour Indonesia, dalam hal ini berawal dari KPPUyang menyatakan bahwa PT Carrefour Indonesia melakukan monopoli dengan cara mengakuisisi Alfa Retailindo. Saat itu market share Carrefour 14,5\% dan setelah mengakuisisi Alfa Retailindo menjadi 17\% sehingga tidak terjadi monopoli dan posisi dominan pada pasar bersangkutan, akhirnya KPPU dinyatakan kalah dalam tingkat MA ${ }^{4}$.

Permasalahan penelitian ini adalah bagaimana dampak hukum putusan Majelis Hakim kasasi yang tidak mempertimbangkan dan memeriksa keberatan/tuntutan dari pemohon kasasi termasuk adanya keterangan saksi yang bersifat mendengar dari orang lain (testimonium de auditu) dan bukti tidak langsung (circumstantial evidence/indirect evidence) sebagai alat bukti persidangan?

\section{PEMBAHASAN}

\section{Indirect Evidence dalam Undang-Undang No. 5 Tahun 1999}

Hukum persaingan usaha adalah hukum yang mengatur segala sesuatu yang berkaitan dengan persaingan usaha, adapun istilah-istilah yang digunakan dalam bidang hukum ini selain istilah hukum persaingan usaha (competition law), yakni hukum hukum antitrust (antitrust law) dan antimonopoli (antimonopoly law). Namun demikian, istilah hukum persaingan usaha telah diatur dan sesuai dengan substansi ketentuan UU No.5 Tahun 1999 tentang Larangan Praktik Monopoli dan Persaingan Usaha Tidak Sehat yang mencakup pengaturan antimonopoli dan persaingan usaha dengan segala aspek-aspeknya yang terkait. Lebih lanjut, dapat dikatakan bahwa UU No.5 Tahun 1999 tentang Larangan Praktik Monopoli dan Persaingan Usaha Tidak Sehat itu merupakan instrumen penting dalam mendorong terciptanya efisiensi ekonomi dan menciptakan iklim kesempatan berusaha yang sama bagi semua pelaku usaha. Dengan demikian, eksistensi UU No. 5 Tahun 1999 perlu didorong agar mampu merealisasikan konsep

\footnotetext{
${ }^{3}$ Frans Sayogie, "Pemaknaan Saksi dan Keterangan Saksi dalam Teks Hukum Analisis Putusan Mahkamah Konstitusi Nomor 65/PUUVIII/2010”, Mimbar Sejarah, Sastra, Budaya, dan Agama - Vol. XXIII No.1, Januari 2017, hlm. 104

${ }^{4}$ Aprilan, "Nalisis Putusan Komisi Pengawas Persaingan Usaha Nomor 09/Kppu-L/2009 Dan Putusan Mahkamah Agung Nomor 502 K/Pdt.Sus/2010 Tentangdugaan Kasusmonopolidan Persaingan Usaha Tidak Sehat Yang Dilakukan Oleh Pt Carrefour Indonesia” , Abstrak Tesis, Universitas Muhammadiyah Malang, 12 Mei 2016 , Http://Eprints.Umm.Ac.Id/29779/, Diakses 13 Maret 2021
} 
Law as a Tool to Encourage Economic Efficiency, sesuai teori umum bahwa hukum adalah alat sosial yang mempromosikan efisiensi ekonomi, analisis ekonomi, dan efisiensi sebagai citacita pedoman penegakan hukum ${ }^{5}$. Lebih lanjut Theo Huijbers dalam Hartanto, menyatakan bahwa hukum memiliki hubungan yang erat dengan keadilan ${ }^{6}$.

Yang ingin diwujudkan tersebut selengkapnya tercantum dalam ketentuan Pasal 3 UU No.5 Tahun 1999, yang memuat:

1. Menjaga kepentingan umum dan meningkatkan efisiensi ekonomi nasional sebagai salah satu upaya meningkatkan kesejahteraan rakyat.

2. Mewujudkan iklim usaha yang kondusif melalui pengaturan persaingan usaha yang sehat, sehingga menjamin adanya kepastian kesempatan berusaha yang sama bagi pelaku usaha besar, pelaku usaha menengah, dan pelaku usaha kecil.

3. Mencegah praktik monopoli dan/atau persaingan usaha tidak sehat yang ditimbulkan oleh pelaku usaha.

4. Terciptanya efektivitas dan efisiensi dalam kegiatan usaha.

Dengan telah diberlakukannya Undang-Undang No. 5 Tahun 1999 tentang Larangan Monopoli dan Persaingan Usaha Tidak Sehat, adalah merupakan landasan yuridis filosofis yang tepat, yakni dengan dicantumkannya ketentuan Pasal 33 ayat (1) UUD 1945 sebagai landasan pokok yang kuat bagi perekonomian Indonesia. Maka sudah selayaknya apabila perekonomian Indonesia bertumpu pada ketentuan pasal tersebut yang juga mengandung ciriciri demokrasi ekonomi yang dapat diuraikan sebagai berikut.

1. Perekonomian disusun sebagai usaha bersama berdasar atas asas kekeluargaan.

2. Cabang-cabang produksi yang penting bagi Negara, dan menguasai hajat/ kebutuhan hidup orang banyak dikuasai oleh negara.

3. Bumi, air dan kekayaan alam di dalamnya dikuasai negara untuk dipergunakan sebesar-besarnya bagi kemakmuran rakyat.

4. Perekonomian nasional diselenggarakan atas dasar demokrasi ekonomi dengan prinsip-prinsip kebersamaan, efisiensi berkeadilan, berkelanjutan, berdasar wawasan lingkungan, mandiri, dengan menjadi keseimbangan kemajuan dan kesatuan ekonomi nasional.

Secara khusus yang perlu diketahui adalah bahwa kebijakan negara ingin melindungi stabilitas sistem kompetisi (preserve competitive system) yang adil agar meningkatkan investasi dan menciptakan lapangan pekerjaan dan memberi keadalilan, seperti di negara-negara maju ${ }^{7}$. Dasar Hukum dan Definisi Monopoli pada pasal 1 ayat 1 Undang-Undang Nomor 5 Tahun 1999 tentang Larangan Praktik Monopoli dan Persaingan Usaha Tidak Sehat, menyatakan bahwa:

\footnotetext{
${ }^{5}$ Rashesh Vaidya, 2018, "Economic Jurisprudence: A Nepalese legal perspective”, International Journal of Law, Volume 4; Issue 6; India, hlm. 100

${ }^{6}$ Hartanto, "Eksistensi Deradikalisasi Dalam Konsep Pembebasan Bersyarat Bagi Narapidana Terorisme", Jurisprudentie, Volume 6, Nomor 1, Juni 2019, hlm. 62

7 Aldo Rico Geraldi, 2018, Personalitas Hukum World Trade Organization Bagi Negara Berkembang Terkait Sistem Perdagangan Antar Negara, Jurnal Komikasi Hukum, Undiksha, Vol 4 No. 1. hlm.11
} 
"Monopoli adalah penguasaan atas produksi dan/ atau pemasaran barang dan/ atau atas penggunaan jasa tertentu oleh satu pelaku usaha atau satu kelompok pelaku usaha."

Monopoli dalam pasal tersebut bermakan suatu penguasaan/ kuasa terhadap suatu bisnis/ atau usaha tertentu oleh satu pelaku usaha atau satu kelompok pelaku usaha. Hal ini bertujuan menghindari posisi dominan seorang/sekelompok pelaku usaha dan disisi lain posisi pesaingnya menjadi lemah, maka semakin lama pelaku usaha yang melakukan penguasaan akan semakin menguasai pasaran.

Pengertian praktek monopoli dan persaingan usaha tidak sehat menurut Undang-Undang No. 5 Tahun 1999 tentang Larangan Praktik Monopoli dan Persaingan Usaha Tidak Sehat terdapat pada Pasal 1 angka 2 dan angka 6:

"Praktek monopoli adalah pemusatan kekuatan ekonomi oleh satu atau lebih pelaku usaha yang mengakibatkan dikuasainya produksi dan atau pemasaran atas barang dan atau jasa tertentu sehingga menimbulkan persaingan usaha tidak sehat dan merugikan kepentingan umum."

Pengertian persaingan usaha tidak sehat terdapat pada Pasal 1 angka 6, yang menyatakan: "Persaingan usaha tidak sehat adalah persaingan antara para pelaku usaha dalam menjalankan kegiatan produksi dan atau pemasaran barang dan atau jasa yang dilakukan dengan cara tidak jujur atau melawan hukum atau menghambat persaingan usaha”

Pengertian kartel diatur Pasal 11, yaitu larangan bagi pelaku usaha dalam menyusun perjanjian, dengan pesaingnya, yang bertujuan untuk mempengaruhi harga dengan mengatur produksi dan atau pemasaran (barang dan/ atau jasa), yang dapat menimbulkan terjadinya praktek monopoli dan atau persaingan usaha tidak sehat. Kata "dapat" dalam hal ini jika tidak dibuktikan secara konkrit berpotensi menimbulkan ketidakpastian hukum, sehingga sulit untuk mencapai keadilan melalui dasar-dasar pembuktian yang nyata.

Majelis Komisi dalam memutuskan suatu perkara persaingan usaha diwajibkan untuk menggunakan alat bukti sebagaimana ditetapkan secara limitatif dalam Pasal 42 UU No.5 Tahun 1999, yakni: (1) keterangan saksi, (2) keterangan ahli, (3) surat dan atau dokumen, (4) petunjuk, dan (5) keterangan pelaku usaha. Pasal 42 tersebut tidak mengatur adanya bukti tidak langsung. Bukti tidak langsung adalah bukti yang secara langsung tidak dapat menunjukkan terjadinya suatu peristiwa hukum atau perbuatan hukum sebagaimana disebutkan dalam UU. ${ }^{8}$ Lebih lanjut dinyatakan bahwa yang penting dalam penggunaan bukti tidak langsung adalah, bukti tidak langsung yang dimaksud harus dilihat dalam hubungan/ rangkaian dengan semua bukti lainnya.

Majelis hakim melalui Putusan Nomor 294 K/PDT.SUS/2012 berpendapat bahwa bukti tidak langsung (indirect evidence) tidak dapat dipersamakan dengan Alat-alat bukti

\footnotetext{
${ }^{8}$ Ingrid Gratsya Zega, “Tinjauan Mengenai Indirect Evidence (Bukti Tidak Langsung) Sebagai Alat Bukti Dalam Kasus Dugaan Kartel Fuel Surcharge Maskapai Penerbangan Di Indonesia", Thesis. Jakarta, Program Pasca Sarjana Fakultas Hukum Universitas Indonesia, 2012, hlm 25
} 
pemeriksaan Komisi dalam Pasal 42 Undang-Undang No. 5 Tahun 1999 tentang Larangan Monopoli dan Persaingan Usaha Tidak Sehat, dan tidak dikenal dalam Undang-Undang Nomor 5 Tahun 1999. Bukti tidak langsung tidak sama dengan bukti petunjuk sebagaimana diatur dalam Pasal 188 ayat (2) KUHAP mengingat perkara persaingan usaha menganut prinsipprinsip hukum pidana. ${ }^{9}$

Meskipun KPPU mempunyai fungsi penegakan hukum khususnya hukum persaingan usaha, namun KPPU bukanlah Lembaga peradilan khusus peradilan usaha, dengan demikian KPPU tidak berwenang menjatuhkan sanksi baik pidana maupun perdata. Kedudukan KPPU lebih merupakan Lembaga administratif ${ }^{10}$.

Pendekatan dalam menganalisis hukum persaingan usaha dapat menggunakan dua pendekatan, yaitu Per se Illegal yang mendasarkan pada adanya bukti perjanjian dan mengesampingkan pembuktian lanjut (rinci) dan pendekatan Rule of Reason menggunakan pembuktian satu alat bukti dan alat bukti lain yang terkait dan pembuktian terjadinya perbuatan yang dilarang, ${ }^{11}$ dalam putusan ini tampaknya hakim menggunakan doktrin Rule of Reason .

\section{Kronologi Perkara}

Perkara ini berawal dari Putusan Komisi Pengawas Persaingan Usaha (KPPU) yang menjatuhkan sanksi administratif terhadap AHM dan YIMM karena dianggap telah memonopoli pasar kendaraan bermotor roda dua skuter matic dengan bekerja sama dalam menentukan harga jual di pasaran, dengan itu KPPU menjatuhkan sanksi sebesar 25.000.000.000 (Dua Puluh Lima Miliar Rupiah) kepada AHM dan 22.500.000 (Dua Puluh Dua Miliar Lima Ratus Juta Rupiah) kepada YIMM, di dalam putusan KPPU No.04/KPPUI/2016 tanggal 20 Februari 2017 terkait dengan Pelanggaran Pasal 5 ayat 1 Tahun 1999 tentang Larangan Praktek Monopoli dan Persaingan Usaha Tidak Sehat. ${ }^{12}$

Selanjutnya pihak AHM (Pemohon Keberatan 1) dan YIMM (Pemohon Keberatan II) mengajukan eksepsi ke Pengadilan Negeri Jakarta Utara yang menjadi dasar pengajuan eksepsi adalah bukti tidak langsung (indirect evidence) dan kesaksian atau keterangan mendengar orang lain (testimonium de auditu) yang diajukan oleh KPPU saat persidangan tidak ada landasan hukumnya berdasarkan Putusan MA No. 897 K/Pdt.Sus/2012 tanggal 25 Februari 2013, namun majelis hakim Pengadilan Negeri Jakarta Utara tetap menolak permohonan keberatan dari AHM dan YIMM dan menguatkan putusan KPPU Nomor 04/KPPU-I/2016 tanggal 20 Februari 2017 melalui Putusan Pengadilan Negeri Jakarta Utara No.163/Pdt.G/KPPU/2017 tanggal 5 Desember 2017.

Dengan ditolaknya eksepsi oleh Pengadilan Negeri Jakarta Utara maka Pihak AHM (Pemohon Kasasi I) dan YIMM (Pemohon Kasasi II) mengajukan kasasi ke tingkat Mahkamah Agung dengan tuntutan untuk menerima dan mengabulkan permohonan Kasasi yang dimana Pemohon Kasasi I dan II tidak melanggar Pasal 5 ayat 1 Tahun 1999 tentang Larangan Praktek

\footnotetext{
${ }^{9}$ Silalahi, Udin, \& Isabella Cynthia Edgina, "Pembuktian Perkara Kartel Di Indonesia Dengan Menggunakan Bukti Tidak Langsung (Indirect Evidence)", Jurnal Yudisial, Vol. 10 No.3 Desember 2017, hlm 326

${ }^{10}$ Susanti Adi Nugroho, Hukum Persaingan Usaha di Indonesia, Dalam Teori dan Praktik Serta Penerapan Hukumnya, Jakarta, Kencana Prenada Media Group, Oktober 2012, hlm. 25.

${ }^{11}$ Made Prasasta Primandhika dan I Gede Artha, "Analisis Penerapan Pendekatan Rule Of Reason Dan Per Se Illegal Terhadap Kasus Kartel Di Indonesia", Kertha Semaya, Fakultas Hukum Universitas Udayana, Vol 6 No 7 , 2018, hlm. 3

${ }^{12}$ Wawancara kepada E.S, tanggal 28 Desember 2019, Yogyakarta.
} 
Monopoli dan Persaingan Usaha yang Tidak Sehat, membatalkan Putusan PN Jakarta Utara Nomor 163/Pdt.G/KPPU/2017/PN.Jkt.Utr tanggal 5 Desember 2017 juncto Putusan KPPU Nomor 04/KPPU-I/2016 tanggal 20 Februari 2017, menghukum Termohon Kasasi (KPPU) membayar biaya Perkara. Namun Majelis Hakim Kasasi tetap menolak permohonan Kasasi yang diajukan oleh Pemohon Kasasi I dan Pemohon Kasasi II dengan Putusan Mahkamah Agung No.217 K/Pdt.Sus-KPPU/2019, 23 April 2019.

Berdasarkan kronologi diatas, dengan ditolaknya permohonan Kasasi AHM oleh Majelis Hakim Kasasi dengan begitu dapat diasumsikan bahwa tuntutan yang diajukan oleh AHM dan YIMM tidak diperiksa dengan seksama oleh Majelis Hakim Kasasi dan tetap menguatkan putusan KPPU dan menganggap AHM dan YIMM melanggar pasal 5 ayat (1) tahun 1999, walaupun KPPU menghadirkan bukti yang sah yakni bukti tidak langsung (indirect evidence) dan kesaksian atau keterangan mendengar dari orang lain (testimonium de auditu) hal ini yang dapat menurut pendapat penulis bahwa Majelis Hakim Kasasi menimbulkan ketidakpastian hukum dengan tidak cermat dalam memeriksa keberatan dan tuntutan dari Pemohon Kasasi, dan tetap menganggap bahwa bukti tidak langsung (indirect evidence) dan kesaksian atau keterangan mendengar dari orang lain (testimonium de auditu) tetap menjadi bukti yang sah didalam persidangan walaupun sudah dijelaskan diatas bahwa hal tersebut tidak ada landasan hukum yang mengaturnya. Pendapat penulis seiring dengan pendapat Kuffal, bahwa keterangan saksi yang diutarakan saksi sangat berguna untuk mewujudkan tercapainya kebenaran materiil maka memerlukan telaah relevansi, sedangkan terkait atau relevan tidaknya alat bukti dengan perkara merupakan esensi kekuatan pembuktian yang penting. Alat bukti harus memiliki relevansi yang akan menentukan pertimbangan diterima atau tidaknya bukti tersebut $^{13}$. Dengan kata lain hanya keterangan saksi yang diberikan dalam pemeriksaan di muka sidang pengadilan yang berlaku sebagai alat bukti yang sah (vide Pasal 185 ayat (1) KUHAP).

TABEL I

\section{KRONOLOGIS DUGAAN PENETAPAN HARGA}

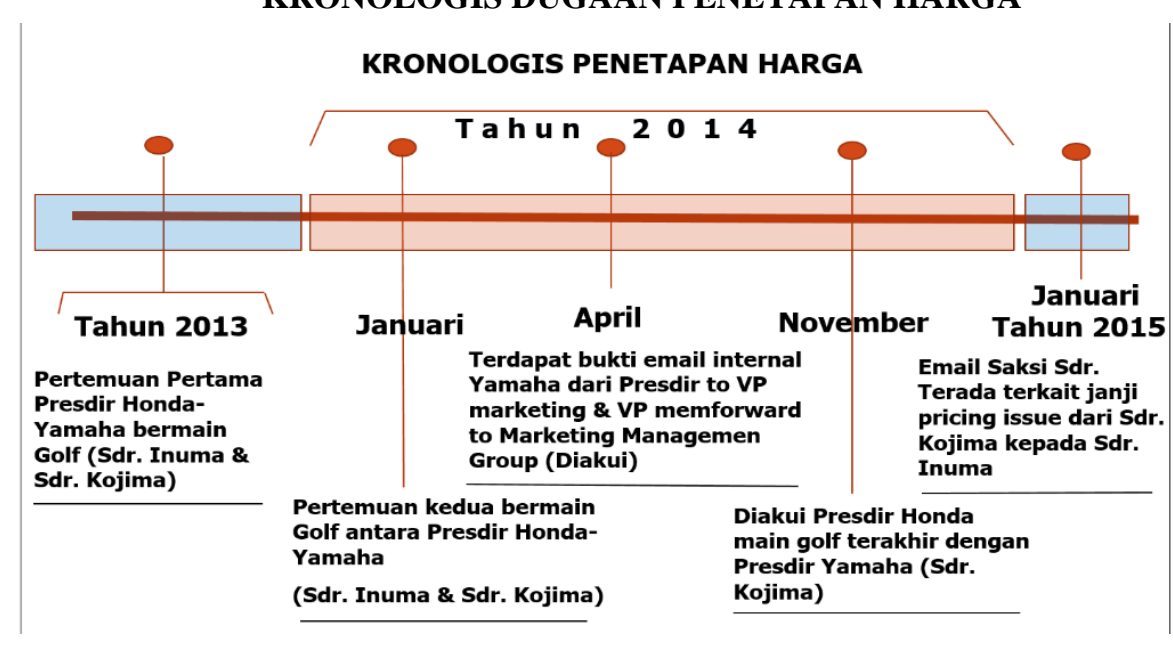

Sumber: Berkas Acara Perkara KPPU

\footnotetext{
${ }^{13}$ HMA Kuffal, Penerapan KUHAP dalam Praktik Hukum, Malang: UMM Press, 2010, hlm. 15
} 


\section{Dampak Hukum dari Putusan Majelis Hakim Kasasi Yang Tidak Mempertimbangkan dan Memeriksa Keberatan atau Tuntutan dari Pemohon Kasasi}

Dalam memeriksa dan memutus suatu perkara, terdapat asas-asas yang menurut hukum harus diterapkan dan dijalankan oleh Hakim. Sudah sepatutnya dan keharusan bagi Majelis Hakim Kasasi untuk memeriksa dan mengadili setiap bagian keberatan/tuntutan yang diajukan.

Terhadap hal ini terdapat asas umum yang wajib dipatuhi untuk tetap memeriksa dan mengadili seluruh bagian keberatan/tuntutan. Asas umum dalam melakukan pemeriksaan terhadap seluruh bagian keberatan/tuntutan tertuang dan digariskan dalam Pasal 53 ayat (2) UU Kekuasaan Kehakiman, Pasal 178 ayat (2) HIR (Herzien Inlandsch Reglement), Pasal 189 ayat (2) RBG (Rechtreglement voor de Buitengewesten)., dan Pasal $50 \mathrm{Rv}$ (Wetboek op de Burgerlijke Rechtvordering).

Namun Majelis Hakim Kasasi diasumsikan tidak memeriksa keseluruhan keberatan dalam Memori Kasasi yang diajukan oleh Pemohon Kasasi I Astra Honda Motor (AHM) yang diantaranya tetap mempertimbangkan keterangan YT sebagai alat bukti saksi yang faktanya YT tidak pernah dihadirkan dan tidak memberi keterangan di bawah sumpah di dalam persidangan, mempertimbangkan keterangan Yuraka Terada dalam BAP adalah testimonium de auditu, dan telah melanggar asas mendengarkan dua belah pihak (audi et alteram partem), tidak dapat membuktikan adanya unsur perjanjian dengan pelaku usaha pesaing, bertentangan dengan Pasal 50 ayat (1) yaitu putusan pengadilan selain harus memuat alasan dan dasar putusan, juga memuat pasal tertentu dari peraturan perundang-undangan yang bersangkutan atau sumber hukum tak tertulis yang dijadikan dasar untuk mengadili juncto Pasal 53 ayat (2) Undang-Undang Kekuasaan Kehakiman. ${ }^{14}$

Majelis Hakim Kasasi dalam hal ini telah mengabaikan aturan-aturan yang menjadi asas umum bagi seorang Hakim dalam melakukan pemeriksaan terhadap suatu bagian keberatan/tuntutan. Lebih lanjut, pemeriksaan terhadap sebagian keberatan/tuntutan mengakibatkan pertimbangan yang tidak cukup dan tidak sesuai dengan asas-asas yang berlaku bagi seorang Hakim dalam memeriksa perkara dimana Hakim tidak diperbolehkan untuk hanya memeriksa dan memutus sebagian dari keberatan atau tuntutan saja yang dalam hal ini tetap menguatkan Putusan PN Jakarta Utara No.163/Pdt.G/KPPU/2017 dengan menolak Kasasi dari Pemohon Kasasi I (AHM).

Pendapat para ahli terkait keberatan terhadap pembuktian dalam perkara ini, adalah sebagai berikut:

1. M. Yahya Harahap dalam bukunya yang berjudul "Hukum Acara Perdata Tentang gugatan Persaingan, Penyitaan, Pembuktian dan Putusan Pengadilan", sebagaimana dikutip: ${ }^{15}$

"Putusan hakim harus total dan secara menyeluruh memeriksa dan mengadili setiap gugatan. Tidak tepat sebatas memeriksa dan memutus sebagian saja, dan mengabaikan gugatan keseluruhan. Cara mengadili seperti ini bertentangan dengan asas dalam undang-undang. ..."

\footnotetext{
${ }^{14}$ Wawancara dengan ES, tanggal 28 Desember 2019 di Hotel Tentrem Yogyakarta.

15 Yahya M. Harahap, Hukum Acara Perdata Tentang Gugatan Persaingan, Penyitaan, Pembuktian dan Putusan Pengadilan. Jakarta: Sinar Grafika, 2016, hlm. 800.
} 
2. ME. Elijana Tansah, mantan Hakim Pengadilan Negeri dan Pengadilan Tinggi, dan mantan staf ahli Ketua Mahkamah Agung Republik Indonesia, sebagaimana dikutip: ${ }^{16}$ “... karena menurut Pasal 178 ayat (2) HIR, Hakim wajib mengadili segala bagian tuntutan dalam arti termasuk setiap keberatan hal mana berarti setiap tuntutan/keberatan harus dipertimbangkan satu persatu apakah mempunyai dasar hukum untuk dikabulkan/dibenarkan apa tidak sehingga dapat dikabulkan atau tidak."

Beberapa yurisprudensi M.A. menyatakan suatu putusan harus dibatalkan jika mendasarkan pertimbangan yang tidak jelas dan cukup. Dibawah ini penulis membandingkan putusan M.A yang ada, sebagai berikut:

1. Putusan Mahkamah Agung No.638 K/Sip/1969

"Bahwa putusan yang kurang cukup dipertimbangkan harus dibatalkan ..."

2. Putusan Mahkamah Agung No.2461 K/Pdt/1984

"Judex Factie dianggap salah menerapkan hukum dan sekaligus putusan yang dijatuhkan dinyatakan tidak cukup pertimbangan sebab terdapat ketidak seksamaan dan rinci, dalam menilai, mempertimbangkan segala fakta yang ditemukan dalam proses persidangan"

3. Putusan Mahkamah Agung No.588 K/Sip/1975

"Putusan Pengadilan Tinggi dan Pengadilan Negeri, karena kurang tepat dan tidak disertai dengan alasan yang jelas dan terperinci, maka harus dibatalkan"

Berdasarkan uraian-uraian di atas terkait dengan kewajiban hakim untuk mengadili atas segala bagian keberatan/tuntutan, penulis berpendapat bahwa Majelis Hakim Kasasi kurang cermat / cukup karena tidak memeriksa keseluruhan keberatan dan berpotensi melanggar Pasal 53 ayat (2) UU Kekuasaan Kehakiman, Pasal 178 ayat (2) HIR, Pasal 189 ayat (2) Rbg., dan Pasal 50 Rv. Oleh karenanya, muncul alasan untuk membatalkan Putusan Mahkamah Agung karena bilamana tidak, hal tersebut berpotensi memimbulkan ketidakadilan bagi salah satu pihak.

\section{Akibat Hukum dari Putusan Majelis Hakim Kasasi Yang Tetap Menggunakan Keterangan Saksi Yang Bersifat Kesaksian atau Keterangan Karena Mendengar dari Orang Lain (Testimonium De Auditu) dan Bukti Tidak Langsung (Circumstantial Evidence/Indirect Evidence) Sebagai Alat Bukti Persidangan}

Keterangan testimonium de auditu yang digunakan oleh KPPU atau Termohon Kasasi merupakan pangkal masalah dan dasar utama untuk menduga adanya pelanggaran Pasal 5 ayat (1) UU Persaingan Usaha dalam perkara a quo. KPPU menggunakan keterangan dari saudara YT yang tidak mengalami, tidak melihat, dan tidak mendengar sendiri suatu peristiwa (testimonium de auditu) yang dijadikan pertimbangan utama oleh KPPU, Majelis Hakim PN Jakarta Utara, dan Majelis Hakim Kasasi dalam menghukum AHM karena melanggar Pasal 5 ayat (1) UU Persaingan Usaha.

\footnotetext{
${ }^{16}$ Dalam pendapat hukum tertulis pada 30 Oktober 2019, pada Angka 3 dan 4 hlm.3
} 
Keterangan YT yang bersifat testimonium de auditu yang katanya berasal dari keterangan Y. Kojima, Presiden Direktur Yamaha, telah dibantah sendiri oleh Y.Kojima dalam persidangan tanggal 16 November 2016 yang menyatakan pada pokoknya tidak ada pembicaraan ataupun perjanjian mengenai kesepakatan harga dengan Presiden Direktur AHM dalam acara permainan golf dan keterangan YT merupakan keterangan yang salah dan tidak benar. ${ }^{17}$

Selain itu, keterangan YT yang bersifat testimonium de auditu juga tidak dapat dianggap dan tidak dapat diterima sebagai alat bukti yang sah menurut ketentuan perundang-undangan yang berlaku dan pendapat para ahli yang memiliki kompetensi untuk menjelaskan mengenai keterangan testimonium de auditu menurut sistem pembuktian di Indonesia.

Keterangan testimonium de auditu YT yang digunakan oleh KPPU/Termohon Kasasi tidak sesuai dengan alat-alat bukti yang telah diungkapkan di dalam persidangan berikut:

1. keterangan saksi-saksi yang telah diperiksa;

2. surat-surat dan/atau dokumen-dokumen yang telah disampaikan; dan

3. keterangan Pemohon PK dan Yamaha/Turut Termohon Kasasi sebagai Terlapor.

Dalam Putusan Mahkamah Agung, Majelis Hakim Kasasi menyatakan bahwa Putusan PN Jakarta Utara dan Putusan KPPU tidak bertentangan dengan hukum, padahal KPPU menggunakan keterangan yang bersifat testimonium de auditu sebagai alat bukti dan telah terbukti juga di dalam persidangan bahwa keterangan testimonium de auditu tersebut tidak benar.

Berdasarkan hukum acara yang berlaku di Indonesia, testimonium de auditu tidak dapat digunakan dan tidak diakui dalam sistem pembuktian di Indonesia, termasuk UU Persaingan Usaha dan Peraturan Komisi/Perkom No.1/2010. Testimonium de auditu tidak dapat disebut sebagai keterangan saksi dan oleh karena itu tidak memiliki kekuatan pembuktian. Prinsip yang sama juga berlaku dalam halnya keterangan tersebut dimuat dalam suatu dokumen, sekalipun dokumen tersebut berupa berita acara pemeriksaan ("BAP"). Selama keterangan dalam BAP bersifat testimonium de auditu, maka keterangan dan dokumen tersebut (BAP) menjadi tidak memiliki kekuatan pembuktian.

Hal ini diperkuat dengan beberapa ketentuan dalam Perkom No.1/2010 maupun peraturan lainnya, dan pendapat-pendapat hukum di bawah ini:

1. Pasal 1 angka 14 Perkom No.1/2010:

"Saksi adalah setiap orang atau pihak yang mengetahui terjadinya pelanggaran dan memberikan keterangan guna kepentingan Pemeriksaan."

2. Pasal 42 UU Persaingan Usaha jo. Pasal 51 ayat (2) jo. Pasal 72 ayat (1) Perkom No.1/2010:

a. Pasal 42 UU Persaingan Usaha "Alat-alat bukti pemeriksaan Komisi berupa:

1) keterangan saksi,

2) keterangan ahli,

3) surat dan atau dokumen,

4) petunjuk,

5) keterangan pelaku usaha."

b. Pasal 51 ayat (2) Perkom No.1/2010:

\footnotetext{
${ }^{17}$ Wawancara dengan E S, tanggal 28 Desember 2019 di Hotel Tentrem Yogyakarta.
} 
"Keterangan Saksi dianggap sebagai alat bukti apabila keterangan yang diberikan dalam Sidang Majelis Komisi berkenaan dengan hal yang dialami, dilihat, atau didengar sendiri oleh Saksi;",

3. Pasal 72 ayat (1) Perkom No.1/2010

"Dalam menilai terjadi atau tidaknya pelanggaran, Majelis Komisi menggunakan alatalat bukti berupa:

a. Keterangan Saksi;

b. Pendapat Ahli;

c. Surat dan/atau dokumen;

d. Petunjuk;

e. Keterangan Terlapor."

4. Pasal 1 angka 27 Undang-Undang No.8 Tahun 1981 tentang Hukum Acara Pidana ("KUHAP")

"Keterangan saksi merupakan salah satu alat bukti dalam perkara pidana yang berupa keterangan dari saksi mengenai suatu peristiwa pidana yang ia dengar dan lihat sendiri dan ia alami sendiri dengan menyebukant alasan dari pengetahuannya tersebut."

5. Dr. Kurnia Toha, S.H., LL.M., berpendapat bahwa: ${ }^{18}$

"Saksi adalah orang yang mengalami langsung, yaitu mengetahui, melihat dan mendengar langsung tindakan pelanggaran hukum yang disangkakan."

Maka mendasarkan Pasal 1 angka 27 KUHAP, sehingga: testimonium de auditu atau keterangan saksi yang ia peroleh sebagai hasil pendengaran dari orang lain, "tidak mempunyai nilai sebagai alat bukti” keterangan saksi disidang pengadilan berupa keterangan ulangan dan apa yang didengarnya dari orang lain, tidak dapat dianggap sebagai alat bukti, "pendapat" atau "rekaan" yang saksi peroleh dari hasil pemikiran, bukan merupakan keterangan saksi ${ }^{19}$. Sebagai pembanding jika berdasar penafsiran sistematis maka Pasal 1 angka 27 KUHAP, menyatakan alat bukti yang sah disebut keterangan saksi, hanyalah keterangan saksi yang bersumber dari suatu peristiwa pidana, berdasar:

a. Pendengaran sendiri;

b. Pengelihatan sendiri; dan

c. Pengalaman sendiri.

Ketentuan inilah yang dianut hukum positif Indonesia. Dengan demikian sistem peradilan pidana Indonesia "mengecualikan" testimonium de auditu sebagai alat bukti" atau setidak-tidaknya downgrade memiliki kualitas pembuktian yang lebih rendah dari yang diatur Pasal 1 angka 27 KUHAP.

6. Prof. Dr. Jur. Andi Hamzah, dalam buku "Hukum Acara Pidana Indonesia", sebagaimana dikutip: ${ }^{20}$

"Dalam Pasal 185 ayat (5) KUHAP menyatakan perihal baik itu pendapat atau rekaan, yang diperoleh dari pemikiran (penalaran), bukan merupakan keterangan

\footnotetext{
${ }^{18}$ Pendapat Ahli pada persidangan tanggal 15 Desember 2016

${ }^{19}$ Bastianto Nugroho, "Peranan Alat Bukti Dalam Perkara Pidana Dalam Putusan Hakim Menurut Kuhap", Jurnal Yuridika, Fakultas Hukum Universitas Airlangga, Vol 3, No. 1, 2017, hlm. 28

20 Andi Hamzah, Hukum Acara Pidana Indonesia, Jakarta: Sinar Grafika, 2010, hlm.264-265
} 
saksi. Kemudian Pasal 185 ayat (1) "keterangan saksi tidak termasuk keterangan yang didapat dari orang lain/ testimonium de auditu”. Maka dapat disimpulkan dengan tegas perihal keterangan saksi yang bersumber dari pihak lain dimaknai bukan alat bukti sah. Keterangan semacam ini yaitu keterangan saksi yang diperoleh dari mendengar orang lain menceritakan atau mengatakan sesuatu, atau testimonium de auditu atau hearsay evidence.

Menurut pendapat penulis, sesuai dengan penjelasan KUHAP yang mengatakan kesaksian de auditu tidak diperkenankan sebagai alat bukti dan patut tidak dipakai di Indonesia pula."

7. Prof. Dr. Nindyo Pramono, memberikan pendapat: ${ }^{21}$

"Testimoni de auditu adaalah orang yang memperoleh informasi melalui cara tidak langsung, dimana hal ini tidak memenuhi sebagai alat bukti di buku Sudikno."

8. M.E. Elijana Tansah, mantan Hakim Pengadilan Negeri dan Pengadilan Tinggi, dan mantan staf ahli Ketua Mahkamah Agung Republik Indonesia, dalam pendapat hukum tertulis:

"Keterangan saksi yang bersifat testimonium de auditu harus/wajib untuk dikesampingkan oleh Hakim/Majelis hakim yang memeriksa perkara. Mengingat aturan beracara di Indonesia (KUHP), baik perdata, pidana, maupun hukum acara yang khusus (dalam hal ini hukum acara persaingan usaha), tidak mengakui testimonium de auditu."

“... keterangan saksi dalam kategori/ sifat testimonium de auditu bukanlah alat bukti keterangan saksi. Perlu diingat, saksi adalah pihak yang mengetahui sendiri terjadinya pelanggaran dan memberikan keterangan guna kepentingan pemeriksaan, atau dengan kata lain, saksi harus melihat, mendengar, dan atau mengalami sendiri suatu kejadian."

9. Prof. Dr. Ningrum Natasya Sirait, S.H., M.LI., Guru Besar Hukum Persaingan Usaha Universitas Sumatera Utara, yang pada pokoknya baik pada Perkom 1/2010 maupun pada Perkom 1/2019, keterangan ahli testimonium de auditu tidak dianggap sebagai alat bukti: ${ }^{22}$

Angka 3:

“... berdasarkan Pasal 1 angka 15 jo. Pasal 46 PerKPPU 1/2019, pembuktian dengan menggunakan keterangan saksi yang tidak dialami, tidak dilihat, atau tidak didengar oleh Saksi sendiri (dalam pertanyaan ini dimaknai sebagai "bersifat testimonium de auditu”) tidak dapat dianggap sebagai alat bukti..."

Angka 4:

"Keterangan saksi dengan sifat testimonium de auditu tidak dapat digunakan dan tidak memiliki nilai pembuktian, hal ini berdasar pada Pasal 15 jo. Pasal 46 PerKPPU $1 / 2019$ di atas.

Dalam hal keterangan saksi yang bersifat testimonium de auditu tersebut diterima sebagai alat bukti yang sah dan dipergunakan sebagai alat bukti dalam pengambilan putusan, maka

\footnotetext{
${ }^{21}$ Pendapat Ahli pada persidangan tanggal 22 Desember 2016

${ }^{22}$ Dalam pendapat hukum tertulis pada 14 November 2019, pada Angka 3 dan 4 hlm. 3
} 
perlu dipastikan terlebih dahulu, apakah alat bukti dalam pengambilan putusan tersebut hanyalah atas dasar 2 (dua) alat bukti dan salah satunya adalah keterangan saksi yang bersifat testimonium de auditu tersebut? Apabila demikian, maka putusan tersebut cacat hukum karena putusan diambil hanya atas dasar 1 (satu) alat bukti yang sah dan seharusnya batal demi hukum."

Meskipun pengaturan alat bukti "keterangan saksi" yang dikenal dalam hukum acara yang berlaku di Indonesia, seharusnya termasuk peraturan persaingan usaha, tidak mengenal penggunaan alat bukti yang bersifat testimonium de auditu, namun Majelis Hakim Kasasi tetap menerima keterangan YT yang bersifat testimonium de auditu sebagai alat bukti yang memiliki kekuatan menentukan.

Majelis Hakim Kasasi daapt dianggap kurang cermat, karena tidak memeriksa secara seksama bahwa keterangan YT yang bersifat testimonium de auditu telah dibantah oleh keterangan saksi-saksi yang diperiksa dalam persidangan yang merupakan keterangan saksi yang dikenal dalam UU Persaingan Usaha dan Perkom No.1/2010.

Komisi Pengawas Persaingan Usaha hanya menggunakan email internal Yamaha dan analisis ekonomi yang tidak cukup layak untuk digunakan dan terbukti salah. Email internal Yamaha dan analisis ekonomi terhadap kenaikan harga skuter matik AHM yang dibuat oleh KPPU tidak memiliki persesuaian dengan alat bukti lain yang diungkapkan dalam persidangan.

Terkait perkara a quo, KPPU berasumsi bahwa (i) pertemuan para warga negara Jepang di lapangan golf telah menghasilkan perjanjian penetapan harga (walaupun KPPU, dalam persidangannya tidak pernah membuktikan apa yang dibahas dalam pertemuan di lapangan golf tersebut), dan (ii) setelah itu terdapat email internal Yamaha pada tanggal 28 April 2014, tanpa didasarkan pada bukti-bukti dan kaidah hukum pembuktian yang valid.

Majelis Hakim Kasasi dianggap kurang cermat karena menolak Permohonan Kasasi AHM dan hanya memberikan pertimbangan bahwa Putusan PN Jakarta Utara dan Putusan KPPU tidak bertentangan dengan hukum, tanpa mempertimbangkan alat bukti lain yang diungkap dalam persidangan dan kaidah hukum yang berlaku dalam sistem hukum pembuktian di Indonesia. Bukti tidak langsung (indirect evidence) yang berdiri sendiri tanpa ada kaitannya dengan alat bukti lain bukan merupakan alat bukti yang diakui dalam hukum acara pembuktian di Indonesia, termasuk hukum acara persaingan usaha.

Selain bukti tidak langsung (indirect evidence) yang digunakan KPPU tidak memiliki persesuaian dengan alat bukti lain yang diungkapkan dalam persidangan, terdapat beberapa putusan Mahkamah Agung yang dengan jelas menolak bukti tidak langsung (indirect evidence) masuk ke dalam kategori alat bukti menurut hukum pembuktian di Indonesia, sebagai berikut:

1. Putusan Mahkamah Agung No.582 K/Pdt.Sus/2011 tanggal 25 November 2011:

"Bahwa alasan-alasan tersebut tidak dapat dibenarkan, Judex Facti tidak salah menerapkan hukum, oleh karena Pemohon Kasasi dalam putusannya Nomor 4/KPPUI/2009 tanggal 4 Mei 2010, yang menyatakan para Termohon Kasasi telah melanggar Pasal 4, Pasal 5 dan Pasal 11 UU Nomor 5 Tahun 1999 dengan menerapkan sistem indirect evidence yang tidak dikenal dalam Hukum Pembuktian Persaingan Usaha yang diatur dalam Pasal 42 UU Nomor 5 Tahun 1999;”

2. Putusan Mahkamah Agung 294 K/PDT.SUS/2012 tanggal 28 Juni 2012

"Bahwa Pelanggaran Pasal 5 Undang-Undang No.5 Tahun 1999: terkait dengan telah terjadi praktek kartel oleh para pelaku usaha. Bukti tidak langsung tidak sama dengan 
alat bukti dalam Pasal 42 Undang Undang No.5 Tahun 1999 dan tidak dikenal dalam Undang-Undang di Indonesia. Bukti tidak langsung tidak sama dengan alat bukti petunjuk sebagaimana diatur dalam Pasal 188 ayat (2) KUHAP, mengingat perkara persaingan usaha menganut prinsip-prinsip hukum pidana"

3. Putusan Mahkamah Agung No.897 K/Pdt.Sus/2012 tanggal 25 Februari 2013, yang pada pokoknya menjelaskan bahwa bukti tidak langsung (indirect evidence) tidak dikenal berdasarkan hukum yang berlaku di Indonesia.

Selain itu, Ahli Prof. Dr. Ningrum Natasya Sirait, S.H., M.LI., dalam pendapat hukum tertulis, pada pokoknya menjelaskan bahwa KPPU/Termohon Kasasi tidak mengenal pembuktian dan tidak pernah memuat ketentuan secara tegas sehubungan dengan penggunaan bukti tidak langsung (indirect evidence) berdasarkan Perkom No.1/2010. ${ }^{23}$

Namun, Majelis Hakim Kasasi tetap mempertimbangkan dan menerima email internal Yamaha dan analisis ekonomi yang salah terkait kenaikan harga Honda dan Yamaha. Padahal Perkom No.1/2010 yang digunakan dalam perkara a quo tidak mengatur dan tidak mengenal pembuktian dengan menggunakan bukti tidak langsung (indirect evidence).

Oleh karena Majelis Hakim Kasasi terbukti telah mempertimbangkan kondisi bukti tidak langsung (indirect evidence) yang tidak diakui secara tegas dalam hukum acara di Indonesia dan seandainya pun diakui, quod non, bukti tidak langsung (indirect evidence) tersebut tidak memiliki persesuaian dengan alat bukti lainnya.

Berdasarkan penjelasan diatas maka, hal ini akan mengakibatkan putusan tersebut tidak $\mathrm{sah}^{24}$ dan tentu dapat menimbulkan ketidakpastian hukum karena tidak adanya aturan atau Undang-Undang yang berlaku yang mengatur mengenai bukti tidak langsung (indirect evidence) dan keterangan saksi yang bersifat mendengar dari orang lain (testimonium de auditu) di sistem peradilan Indonesia.

Tabel II

Pricelist Yamaha Mio dan Honda Beat Tahun 2013

\begin{tabular}{|c|c|c|c|c|c|c|c|c|c|c|c|c|}
\hline \multicolumn{13}{|c|}{ Harga Pricelist Rekomendasi untuk Konsumen } \\
\hline \multirow{2}{*}{$\frac{\text { Skutik } 110 \text { CC }}{\text { Tipe }}$} & \multicolumn{12}{|c|}{ Tahun 2013} \\
\hline & Jan & Feb & Mar & Apr & Mei & Juni & Juli & Agus & Sep & Okt & Nov & Des \\
\hline Mio J CW Teen & 13,100 & 13,250 & 13,250 & 13,250 & 13,250 & 13,250 & 13,250 & 13,300 & 13,300 & 13,350 & 13,350 & 13,350 \\
\hline Mio GT & - & 13,350 & 13,350 & 13,350 & 13,350 & 13,350 & 13,350 & 13,500 & 13,500 & 13,550 & 13,550 & 13,550 \\
\hline Beat FICW & 12,900 & 12,900 & 13,000 & 13,000 & 13,000 & 13,150 & 13,150 & 13,150 & 13,150 & 13,150 & 13,150 & 13,250 \\
\hline Beat FI CBS & 13,500 & 13,500 & 13,650 & 13,650 & 13,650 & 13,800 & 13,800 & 13,800 & 13,800 & 13,800 & 13,800 & 13,800 \\
\hline
\end{tabular}

Sumber: Berkas Acara Perkara Penyidik KPPU

\footnotetext{
${ }^{23}$ Dalam Pendapat Hukum Tertulis pada 14 November 2019, angka 5 s.d 7 hlm. 4 dan 5

${ }^{24}$ Berdasarkan Pasal 42 UU Persaingan Usaha jo. Pasal 51 ayat (2) jo. Pasal 72 ayat (1) Perkom No.1/2010
} 


\section{Tabel III}

Pricelist Yamaha Mio dan Honda beat Tahun 2014

\begin{tabular}{|l|l|l|l|l|l|l|l|l|l|l|l|l|}
\hline \multicolumn{10}{c|}{ Targa Pricelist Rekomendasi untuk Konsumen } \\
\hline Skutik 110 CC & \multicolumn{10}{c|}{ Tahun 2014 } \\
\hline Tipe & Jan & Feb & Mar & Apr & Mei & Juni & Juli & Agus & Sep & Okt & Nov & Des \\
\hline Mio J CW Teen & 13,350 & 13,350 & 13,350 & 13,350 & 13,350 & 13,350 & 13,450 & 13,350 & 13,350 & 13,350 & 13,350 & 13,350 \\
\hline Mio GT & 13,650 & 13,650 & 13,650 & 13,650 & 13,650 & 13,750 & 13,750 & 13,750 & 13,850 & 13,850 & 13,850 & 13,850 \\
\hline Beat FI CW & 13,500 & 13,500 & 13,750 & 13,750 & 13,750 & 13,850 & 13,850 & 13,850 & 13,850 & 13,850 & 13,850 & 13,850 \\
\hline Beat FI CBS & 14,050 & 14,050 & 14,300 & 14,300 & 14,300 & 14,400 & 14,400 & 14,400 & 14,400 & 14,400 & 14,400 & 14,400 \\
\hline
\end{tabular}

Sumber: Berkas Acara Perkara Penyidik KPPU

\section{Tabel IV}

Pricelist Yamaha Xeon dan Honda Vario 125 Tahun 2013

Harga Pricelist Rekomendasi untuk Konsumen

\begin{tabular}{|l|l|l|l|l|l|l|l|l|l|l|l|l|}
\hline Skutik 125 CC & \multicolumn{10}{|c|}{ Tahun 2013 } \\
\hline Tipe & Jan & Feb & Mar & Apr & Mei & Juni & Juli & Agus & Sep & Okt & Nov & Des \\
\hline Xeon RC & - & - & - & - & - & 15,150 & 15,150 & 15,150 & 15,150 & 15,200 & 15,200 & 15,200 \\
\hline Vario 125 Techno/CBS & 15,100 & 15,100 & 15,450 & 15,450 & 15,450 & 15,550 & 15,550 & 15,550 & 15,550 & 15,550 & 15,550 & 15,550 \\
\hline Vario 125 CBS/CBS ISS & 15,900 & 15,900 & 16,350 & 16,350 & 16,350 & 16,450 & 16,450 & 16,450 & 16,450 & 16,450 & 16,450 & 16,450 \\
\hline
\end{tabular}

Sumber: Berkas Acara Perkara Penyidik KPPU

Tabel V

Pricelist Yamaha Xeon dan Honda Vario 125 Tahun 2014

\begin{tabular}{|l|l|l|l|l|l|l|l|l|l|l|l|l|}
\hline \multicolumn{10}{c|}{ Harga Pricelist Rekomendasi untuk Konsumen } \\
\hline Skutik 125 CC & \multicolumn{10}{c|}{ Tahun 2014 } \\
\hline Tipe & Jan & Feb & Mar & Apr & Mei & Juni & Juli & Agus & Sep & Okt & Nov & Des \\
\hline Xeon RC & 15,200 & 15,200 & 15,500 & 15,500 & 15,500 & 15,500 & 15,500 & 15,500 & 15,500 & 15,500 & 15,500 & 15,500 \\
\hline GT 125 & 15,900 & 15,900 & 15,900 & 15,900 & 15,900 & 15,900 & 15,900 & 16,000 & 16,000 & 16,000 & 16,000 & 16,000 \\
\hline Vario 125 Techno/CBS & 15,800 & 15,800 & 16,100 & 16,100 & 16,100 & 16,200 & 16,400 & 16,400 & 16,400 & 16,400 & 16,400 & 16,600 \\
\hline Vario 125 CBS/CBS ISS & 16,700 & 16,700 & 16,800 & 16,800 & 16,800 & 16,900 & 17,100 & 17,100 & 17,100 & 17,100 & 17,100 & 17,300 \\
\hline
\end{tabular}

Sumber: Berkas Acara Perkara Penyidik KPPU

Tabel VI

Pangsa Pasar Honda dan Yamaha dari tahun 2012 s.d 2018

\begin{tabular}{|c|c|c|}
\hline Tahun & Pemohon PK (\%) & Yamaha/Turut Termohon PK (\%) \\
\hline 2012 & 57,3 & 34,1 \\
\hline 2013 & 60,5 & 31,2 \\
\hline 2014 & 63,9 & 30,2 \\
\hline 2015 & 66,8 & 29,1 \\
\hline 2016 & 71,4 & 25,1 \\
\hline 2017 & 71,3 & 25,3 \\
\hline 2018 & 74,6 & 22,8 \\
\hline
\end{tabular}

Sumber: AISI.

Berdasarkan tabel di atas, terbukti bahwa tidak ada penetapan harga atau kartel yang dilakukan oleh Honda dan Yamaha dalam perkara a quo. Apabila terdapat kartel, maka baik Honda dan Yamaha keduanya akan bertambah pangsa pasarnya, namun, pangsa pasar Yamaha malah berkurang dari tahun 2014 s.d. 2018.

Menurut Ahli Prof. Dr. Ningrum Natasya Sirait, S.H., M.LI., Guru Besar Hukum Persaingan Usaha Universitas Sumatera Utara, dalam pendapat hukum tertulis, pada pokoknya 
menjelaskan bahwa dugaan untuk melihat suatu penetapan harga atau kartel yang dilakukan oleh pelaku usaha, salah satunya adalah dengan melihat pangsa pasar para pelaku usaha tersebut. Apabila pangsa pasar para pelaku usaha cenderung naik, maka dapat diduga adanya kartel. Namun, jika salah satu pangsa pasar pelaku usaha turun, maka dapat dipastikan tidak ada kartel yang dilakukan oleh para pelaku usaha tersebut. ${ }^{25}$

Penelitian yang ditulis Rai Manitili, dkk menyatakan bahwa KPPU memiliki kewenangan yang cukup dalam mengatur persaingan usaha di Indonesia, namun banyak pula ditemukan keputusan KPPU yang dibatalkan ketika diajukan kasasi atau keberatan oleh pelaku usaha, ini mengindikasikan adanya kelemahan dalam UU No. 5 Tahun $1999^{26}$. Lebih lanjut mengutip hukumonline.com: Testimonium de auditu, merupakan keterangan saksi yang tidak dapat diterima sebagai alat bukti, contoh Putusan M.A. No. 881 K/Pdt/1983, yang menegaskan saksi-saksi dari penggugat semuanya merupakan de auditu, sehingga MA menganggap keterangan yang mereka sebagai alat bukti dinyatakan tidak sah sah; Secara kasuistik hakim dapat saja mengonstruksi de auditu sebagai saksi, yang diakui menjadi alat bukti persangkaan dengan syarat mempertimbangkan obyektifitas dan rasionalitas. ${ }^{27}$

\section{PENUTUP}

Berdasarkan penjelasan diatas dapat ditarik kesimpulan bahwa Hakim Kasasi kurang cermat karena menolak permohonan kasasi AHM dan hanya memberikan pertimbangan bahwa Putusan PN Jakarta Utara dan Putusan KPPU tidak bertentangan dengan hukum, tanpa mempertimbangkan alat bukti lain yang diungkap dalam persidangan dan kaidah hukum yang berlaku dalam sistem hukum pembuktian di Indonesia. Alat bukti yang dihadirkan sejak awal persidangan hanya bukti email dan keterangan YT (testimonium de auditu) dan dijadikan alat pertimbangan pokok. Bukti tidak langsung (indirect evidence) yang berdiri sendiri tanpa ada kaitannya dengan alat bukti lain bukan merupakan alat bukti yang diakui dalam hukum acara pembuktian di Indonesia, termasuk hukum acara persaingan usaha, atau setidak-tidaknya memiliki nilai pembuktian yang lemah, dan dapat berdampak menurunnya kualitas putusan.

Berdasarkan aturan yang berlaku dan penjelasan beberapa ahli di atas, maka testimonium de auditu tidak dapat dianggap sebagai suatu alat bukti yang sah karena kesaksian harus berasal dari apa yang didengar seseorang dari orang lain dan kesaksian itu tidak dapat menunjukkan kualitas fakta sebenarnya. Hakim Kasasi a quo dapat dianggap mengurangi kualitas putusan hukum, karena tidak menerapkan asas-asas umum bagi seorang hakim dalam memeriksa dan memutus suatu perkara. Hakim Kasasi tidak memeriksa keseluruhan dan keterkaitan keberatan/tuntutan dalam Permohonan dan Memori Kasasi yang AHM ajukan, berdasarkan syarat-syarat yang diwajibkan oleh peraturan perundang-undangan karena:
a. Tidak sesuai dengan Pasal 50 ayat (1) jo. Pasal 53 ayat (2) UU Kekuasaan Kehakiman;
b. melanggar asas audi et alteram partem ("Mendengarkan dua belah pihak");
c. tidak cukup pertimbangan dalam memutus perkara;
d. tidak dapat membuktikan adanya unsur perjanjian dengan pelaku usaha pesaing.

\footnotetext{
${ }^{25}$ Dalam Pendapat Hukum Tertulis pada 14 November 2019, angka 28, hlm 16

${ }^{26}$ Rai Manitili, et.al, "Problematika Penegakan Hukum Persaingan Usaha di Indonesia Dalam Rangka Menciptakan Kepastian Hukum”, Jurnal Unpad, Vol 3, No. 1, 2016, hlm 132

${ }^{27}$ Sovia Hasanah, Arti Testimonium De Auditu, Jumat, hukumonline.com, diakses 13 Maret 2021, melalui https://www.hukumonline.com/klinik/detail/ulasan/lt58dcb3732cca3/arti-itestimonium-de-auditu-i/\#_ftn4
} 
Perlunya revisi UU Larangan Praktik Monopoli dan Persaingan Usaha Tidak Sehat untuk menambah pasal atau menegaskan mengenai alat bukti tidak langsung (indirect evidence) dan kesaksian atau keterangan saksi yang bersifat dari orang lain (testimonium de auditu) supaya dapat memberikan kepastian hukum untuk mencapai keadilan. Disisi hakim senantiasa melakukan upaya untuk meningkatkan kecermatan memeriksa memori kasasi, secara khusus dalam hal meneliti alat bukti, keterkaitan alat bukti, dan kualitas alat bukti, dengan tujuan agar keadilan dapat diupayakan secara maksimal.

\section{DAFTAR PUSTAKA}

\section{Buku}

Andi Hamzah, Hukum Acara Pidana Indonesia, Jakarta: Sinar Grafika, 2010.

HMA Kuffal, Penerapan KUHAP dalam Praktik Hukum, Malang: UMM Press, 2010.

Susanti Adi Nugroho, "Hukum Persaingan Usaha di Indonesia, Dalam Teori dan Praktik Serta

Penerapan Hukumnya", Jakarta: Kencana Prenada Media Group, Oktober 2012.

Yahya M. Harahap Hukum Acara Perdata Tentang Gugatan Persaingan, Penyitaan, Pembuktian dan Putusan Pengadilan. Jakarta: Sinar Grafika, 2016.

\section{Jurnal}

Aldo Rico Geraldi, "Personalitas Hukum World Trade Organization Bagi Negara Berkembang Terkait Sistem Perdagangan Antar Negara”, Jurnal Komunikasi Hukum, Undiksha, Vol 4 No. 1, 2018.

Bambang Sugeng Ariadi Subagyono, "Kajian Penerapan Asas Ultra Petita Pada Petitum Ex Aequo Et Bono", Jurnal Yuridika, Volume 29 No 1, Januari - April 2014, Fakultas Hukum Universitas Airlangga.

Bastianto Nugroho, "Peranan Alat Bukti Dalam Perkara Pidana Dalam Putusan Hakim Menurut Kuhap", Jurnal Yuridika, Fakultas Hukum Universitas Airlangga, Vol 3, No. 1, 2017.

Frans Sayogie, "Pemaknaan Saksi dan Keterangan Saksi dalam Teks Hukum Analisis Putusan Mahkamah Konstitusi Nomor 65/PUUVIII/2010”, Mimbar Sejarah, Sastra, Budaya, dan Agama - Vol. XXIII No.1, Januari 2017.

Hartanto, "Eksistensi Deradikalisasi Dalam Konsep Pembebasan Bersyarat Bagi Narapidana Terorisme", Jurisprudentie, Volume 6 Nomor 1 Juni 2019.

Ingrid Gratsya Zega, “Tinjauan Mengenai Indirect Evidence (Bukti Tidak Langsung) Sebagai Alat Bukti Dalam Kasus Dugaan Kartel Fuel Surcharge Maskapai Penerbangan Di Indonesia", Thesis. Jakarta: Program Pasca Sarjana Fakultas Hukum Universitas Indonesia, 2012.

Laurensius Arliman S, Mewujudkan Penegakan Hukum Yang Baik Di Negara Hukum Indonesia, Dialogia Iuridica, Volume 11 Nomor 1, November 2019, Universitas Kristen Maranatha.

Made Prasasta Primandhika dan I Gede Artha, "Analisis Penerapan Pendekatan Rule Of Reason Dan Per Se Illegal Terhadap Kasus Kartel Di Indonesia", Kertha Semaya, Fakultas Hukum Universitas Udayana, Vol 6 No 7, 2018. 
Rai Manitili, et.al, "Problematika Penegakan Hukum Persaingan Usaha di Indonesia Dalam Rangka Menciptakan Kepastian Hukum”, Jurnal Unpad, Vol 3, No. 1, 2016

Rashesh Vaidya, 2018, "Economic Jurisprudence: A Nepalese legal perspective", International Journal of Law, Volume 4; Issue 6; India.

Silalahi, Udin, \& Isabella Cynthia Edgina, "Pembuktian Perkara Kartel Di Indonesia Dengan Menggunakan Bukti Tidak Langsung (Indirect Evidence)", Jurnal Yudisial, Vol. 10 No.3 Desember 2017.

Supriatna, "Persekongkolan Bisnis Dalam Bentuk Perjanjian Kartel”, Jurnal Hukum Positum, Unsika, Vol. 1, No. 1, Desember 2016.

\section{Peraturan Perundang-Undangan:}

Undang-Undang Dasar 1945

Wetboek op de Burgerlijke Rechtvordering (Rv)

Herzien Inlandsch Reglement (HIR)

Rechtreglement voor de Buitengewesten (RBG)

Undang-Undang No.5 Tahun 1999.

Undang-Undang No.5 Tahun 2004.

Undang-Undang No.3 Tahun 2009.

Undang-Undang No. 48 Tahun 2009.

Peraturan KPPU No.1 Tahun 2010.

\section{Putusan:}

Putusan Mahkamah Agung No.1860 K/Pdt/1984

Putusan Mahkamah Agung No.638 K/Sip/1969

"Putusan-putusan ... yang kurang cukup dipertimbangkan (onvoldoende gemotiveerd) harus dibatalkan ..."

Putusan Mahkamah Agung No.672 K/Sip/1972

"putusan Pengadilan Tinggi harus dibatalkan karena kurang cukup dipertimbangkan (onvoldoende gemotiveerd)"

Putusan Mahkamah Agung No.2461 K / Pdt / 1984

Putusan Mahkamah Agung No.588 K/Sip/1975

"Putusan Pengadilan Tinggi dan Pengadilan Negeri, karena kurang tepat dan tidak disertai dengan alasan yang jelas dan terperinci, maka harus dibatalkan"

Putusan Komisi Pengawas Persaingan Usaha No.04/KPPU-I/2016 tanggal 20 Februari 2017

Putusan Pengadilan Negeri Jakarta Utara No.163/Pdt.G/KPPU/2017/PN.Jkt.Utr tanggal 5 Desember 2017

Putusan Mahkamah Agung No.217 K/Pdt.Sus-KPPU/2019

Putusan Mahkamah Agung No. 881 K/Pdt/1983

\section{Wawancara}

Kepada Bapak ES, tanggal 28 Desember 2019 di Hotel Tentrem Yogyakarta.

Pendapat hukum tertulis pada 30 Oktober 2019

Pendapat hukum tertulis pada 14 November 2019 
Pendapat Hukum Tertulis pada 14 November 2019

\section{Tesis}

Aprilan, "Nalisis Putusan Komisi Pengawas Persaingan Usaha Nomor 09/Kppu-L/2009 Dan Putusan Mahkamah Agung Nomor 502 K/Pdt.Sus/2010 Tentang dugaan Kasus monopoli dan Persaingan Usaha Tidak Sehat Yang Dilakukan Oleh PT. Carrefour Indonesia”, Abstrak Tesis, Universitas Muhammadiyah Malang, Diakses 13 Maret 2021, melalui Universitas Muhammadiyah Malang, Http://Eprints.Umm.Ac.Id/29779

\section{Internet}

Sovia Hasanah, Arti Testimonium De Auditu, Jumat, hukumonline.com, diakses 13 Maret 2021, melalui https://www.hukumonline.com/klinik/detail/ulasan/lt58dcb3732cca3/artiitestimonium-de-auditu-i/\#_ftn4 